\title{
ENHANCING TOOL LIFE AND SURFACE FINISH BY SUPPLYING COOL AIR IN DRY MACHINING OF MS AND AISI-202
}

\section{K. MOHAN ${ }^{1}$,P. SNEHALATHA ${ }^{2}$,P. ARAVINDA KEERTHI ${ }^{3} \&$ P. VINDHYA ${ }^{4}$}

${ }^{1,3,4}$ Assistant Professor, Department of Mechanical Engineering, School of Engineering \& Technology, SPMVV, Tirupati, India ${ }^{2}$ Associate Professor, Department of Mechanical Engineering, School of Engineering \& Technology, SPMVV, Tirupati, India \begin{abstract}
This paper presents a survey on the effect of chilled air application throughout dry machining of MS, AISI202 using single point cutting of HSS. Through the Taguchi design of experiment, 32 experiments are conducted under various cutting parameters such as spindle speed, two standards of depth of cut along with feed rate under traditional dry machining as well as machining under supply of chilled air (at temperature of $15^{\circ} \mathrm{C}$ to $12^{\circ} \mathrm{C}$ ) on lathe machine with HSS cutting tool.
\end{abstract}

The setup was fabricated and used for the supply of chilled air at the set temperature. The surface finish and tool life were measured as the output of material's Machinability justification with the use of equipment such as surface profiler and profile projector.

The results showed that the supply of chilled air has improved, tool life and surface finish by $19.23 \%$ and 23.59\% respectively compared to dry air machining. Due to the supply of chilled air, machining temperature, and tool wear has been reduced. Hence surface finish can be improved significantly. It was found that, Conducted experiments has been enhanced the tool life by reducing the tool wear as well as improvement of surface finish.

KEYWORDS: Single Point HSS Cutting Tool, Mild Steel, Stainless Steel AISI-202,Surface Finish \& Tool Wear

Received: Jun 06, 2020; Accepted: Jun 26, 2020; Published: Jun 30, 2020; Paper Id.: IJMPERDJUN2020153

\section{INTRODUCTION}

Existing day's proliferation of productivity and worth of the machined parts plays a key role in the metal cutting industries at different machining processes. The wear mechanisms are used to reduce the tool life [1].The application of chilled air is used to reduce the temperature of the tool tip along with tool life. The virtue of the air-cooled system can be depicted that, the comparison is made between the dry machining as well as machining under supply of chilled air .Surface roughness is used to determine, the product quality of a mechanical products [3, 4]. To achieve certain desired surface quality, functional behavior is a great concern .

Surface roughness is the another important constituent that, greatly influences the manufacturing cost. [5]. So it states that, lower the surface roughness greater the manufacturing cost. To attain good surface roughness, appropriate machining parameters are required to attempt cutting operations.[4]. Cryogenic treatment is permitted to very low (in minus degree Celsius) temperatures supply on tipped tools worked on heavy brittle materials. Hence we can proceed with low temperature supply at tool-work piece interface point i.e. tool tip and its effects over tool life and surface finish.

Currently, Metal cutting process plays a major role in all the manufacturing industries. Surface Roughness is the 
major attribute to define and evaluate the quality characteristics of the product after it is machined.

\section{EXPERIMENTAL DESIGN}

To procure the ramification of the cool air on surface roughness more number of tests are required to be conducted with four parameters of mixed modes. Taguchi's L8 Orthogonal array provides, eight succession of tests on mild steel and stainless steel AISI202 metal work pieces. The work piece used for experiment is round bar with 50 mm diameter and 250 $\mathrm{mm}$ length.In present work, L8 Orthogonal array is depicted in table1.

Table 1: Orthogonal Array L 8 for Experimentation

\begin{tabular}{|c|c|c|c|}
\hline S. No & $\begin{array}{c}\text { Speed } \\
(\mathbf{r p m})\end{array}$ & $\begin{array}{c}\text { Feed } \\
(\mathbf{m m} / \mathbf{r e v})\end{array}$ & $\begin{array}{c}\text { DOC } \\
(\mathbf{m m})\end{array}$ \\
\hline 1 & 1 & 1 & 1 \\
\hline 2 & 1 & 2 & 2 \\
\hline 3 & 2 & 1 & 1 \\
\hline 4 & 2 & 2 & 2 \\
\hline 5 & 3 & 1 & 2 \\
\hline 6 & 3 & 2 & 1 \\
\hline 7 & 4 & 1 & 2 \\
\hline 8 & 4 & 2 & 1 \\
\hline
\end{tabular}

\section{EXPERIMENTAL DETAILS}

Machine Tool - Semi-Automated Lathe

Work Material - Mild Steel And Stainless Steel AISI 202(40mm Diameter \& 250mm Length)

Cutting Tool -High Speed Steel

Cutting Conditions - Dry Environment, Cool Air Environment

Surface Roughness Measuring Instrument -Mitutoyo SJ-201P

Traverse Speed $-1 \mathrm{~mm} / \mathrm{Sec}$

Measurement - Metric/Inch

Profile Projector -For Measuring Tool Wear

Other Tools-Thermometer,Vapour Compressor set up for chilled air supply

Taly surffor Surface Roughness measurement. 


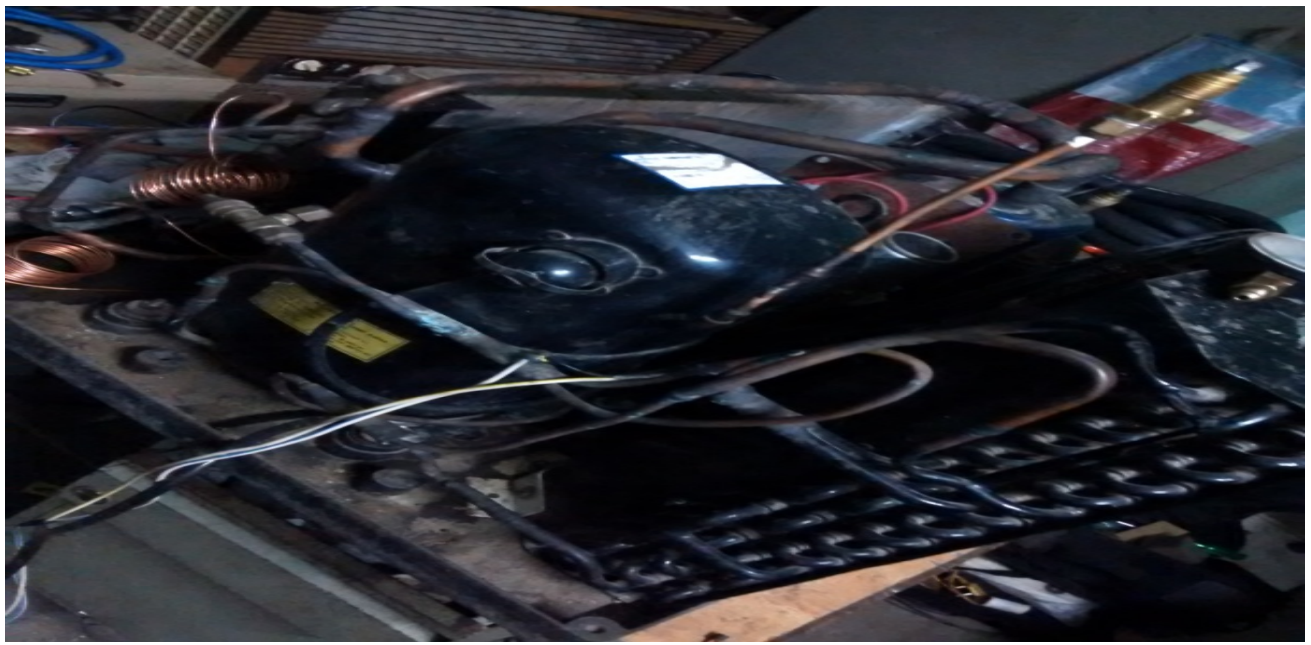

Figure 1: Vapour Compression Setup.

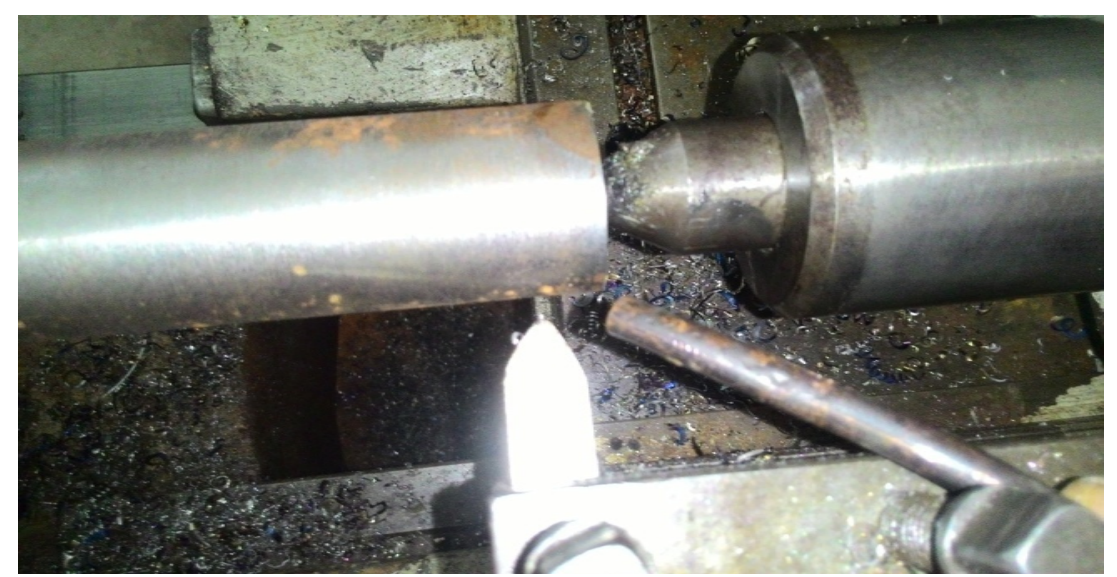

Figure 2: Chilled air Supply at Tool Tip.

\subsection{Experimental Procedure}

With the help of semi-automated lathe machine the work pieces Mild steel, Stainless Steel AISI202 are machined to $200 \mathrm{~mm}$ length at dry conditions i.e. at room temperature and at cool air (at $12^{\circ} \mathrm{C}$ ) with two different jobs by using same cutting tool HSS .First the values are find out at room temperature i.e. dry machining and then the same experiments are repeated supplying cool air by using vapor-compression refrigeration system. In this, two jobs have been performed for this test. Surface Roughness has been done by using portable stylus-type profilometer. The experiment has been repeated to three times and average value were recorded, and then the tool wear is measured by using profile projector. After checking every time the HSS single point cutting tool is regrind to initial machining conditions and the procedure repeated. All tool wear values are for definite and fixed length of $200 \mathrm{~mm}$ of work piece. 


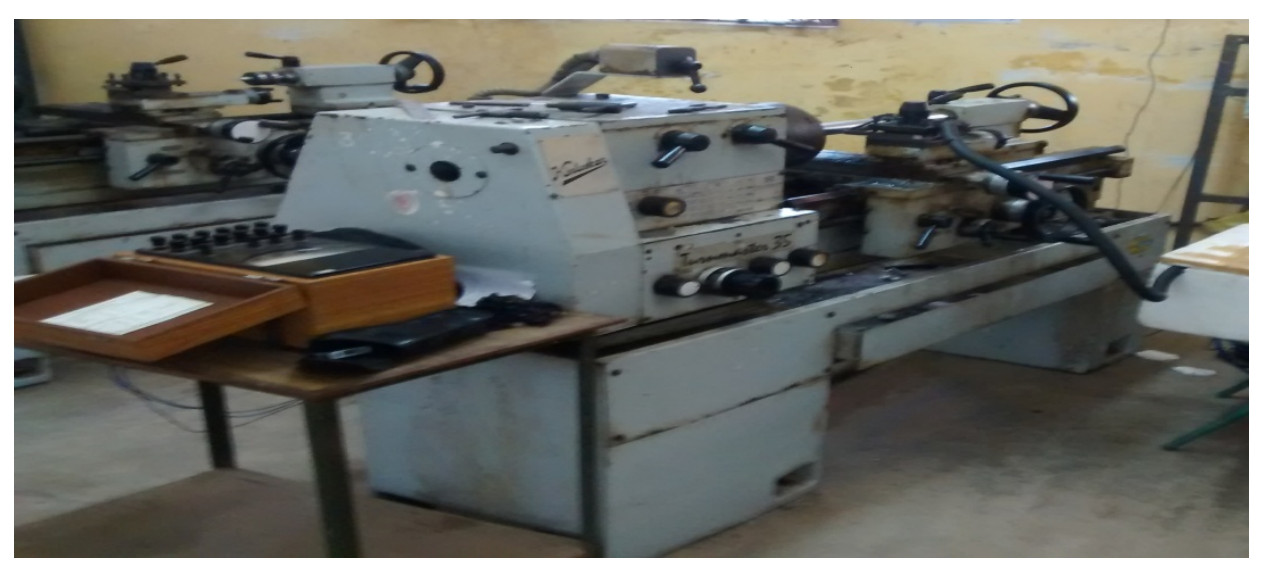

Figure 3: TurnMaster350 Turning Machine.

\subsection{Machine Tool}

Turning operations were conducted on TurnMaster 350 Turning machine which is supplied by JINAGOUDRA Machine Tools (P) LTD. TurnMaster 350 is efficient, precise and economical, which can be used for all turning operations.

Table 2: Specifications of TurnMaster 350

\begin{tabular}{|c|c|}
\hline Made & Jinagoudra Machine Tools (P) LTD. \\
\hline Modal & TurnMaster 350 \\
\hline Capacity & $\begin{array}{l}\text {-height of centre: } 175 \mathrm{~mm}[7 "] \text {-swing over bed: } 350 \mathrm{~mm} \text { [14"]-swing over cross slide: } \\
\text { 200mm [8"]-distance between centers: } 800 \mathrm{~mm}[32 "]\end{array}$ \\
\hline Bed & -bed type: $2 \mathrm{v} \& 2$ flat-bed width: $244 \mathrm{~mm}$ \\
\hline Main spindle & -type \& size of spindle nose: a2-4-taper bore in centre sleeve: $\mathrm{mt}-3$-spindle bore: $40 \mathrm{~mm}$ \\
\hline Tailstock & -quill diameter: 50mm-taper bore in spindle: $\mathrm{mt}-3$-quill travel: $140 \mathrm{~mm}[5.5 "]$ \\
\hline Tool slide & -travel of top slide: $100 \mathrm{~mm}$ [4"]-tool shank section: 20 x $20 \mathrm{~mm}$ \\
\hline Speeds & -no. Of speeds: 8-range: $71-1800 \mathrm{rpm}$ \\
\hline Feeds & $\begin{array}{l}\text {-no. Of longitudinal feeds/range: } 24 / 0.045-0.63 \mathrm{~mm} \text {-no. Of transverse feeds range: } \\
24 / 0.015-0.21 \mathrm{~mm}\end{array}$ \\
\hline Threads & -no. Of metric threads / range:24/0.5 - $0.63 \mathrm{~mm}-$ no. Of inch threads / range: $24 / 56-4$ tpi \\
\hline Electrical & -main motor: $2.2 \mathrm{~kW}$ [3 hp] -power supply: $415 \mathrm{v}, 3 \mathrm{ph}, 50 \mathrm{cps}$, ac supply \\
\hline General & -weight: $800 \mathrm{~kg}$-floor space: 2000 x $850 \mathrm{~mm}-1 * \mathrm{w}: 0.8 \mathrm{~m}$ bed. \\
\hline
\end{tabular}

Table 3: Chemical Properties of MS Table 4: Mechanical Properties of MS

\begin{tabular}{|l|c|}
\hline Carbon & $0.16-0.18 \%$ \\
\hline Silicon & $0.40 \% \max$ \\
\hline Manganese & $0.70-0.90 \%$ \\
\hline Sulphur & $0.040 \% \mathrm{Max}$ \\
\hline Phosphorus & $0.040 \% \mathrm{Max}$ \\
\hline Max Stress & $400-560 \mathrm{n} / \mathrm{mm}^{2}$ \\
\hline Yield Stress & $300-440 \mathrm{n} / \mathrm{mm}^{2} \mathrm{Min}$ \\
\hline $0.2 \%$ Proof Stress & $280-420 \mathrm{n} / \mathrm{mm}^{2} \mathrm{Min}$ \\
\hline Elongation & $10-14 \% \mathrm{Min}$ \\
\hline
\end{tabular}




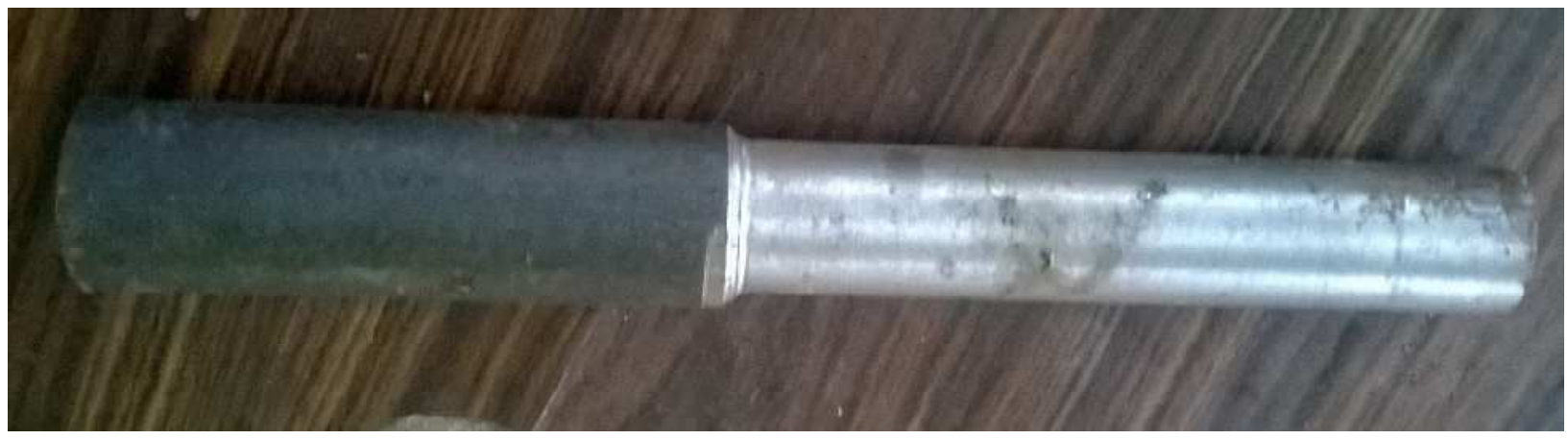

Figure 4: Mild Steel Rod.

AISI 202 Stainless Steel corresponds to the following specifications: UNS20200 / EN1.4373

Table 5: Physical Properties of AISI-202 Table 6: Mechanical Properties of AISI-202

\begin{tabular}{|l|l|}
\hline Density & $7.80 \mathrm{~g} / \mathrm{cm}^{3}$ \\
\hline Thermal Expansion & $17 \times 10-6 / \mathrm{K}$ \\
\hline Modulus of Elasticity & $200 \mathrm{GPa}$ \\
\hline Thermal Conductivity & $15 \mathrm{~W} / \mathrm{m} . \mathrm{K}$ \\
\hline Density & $7.80 \mathrm{~g} / \mathrm{cm}^{3}$ \\
\hline Proof Stress & $310 \mathrm{Min} \mathrm{MPa}$ \\
\hline Tensile Strength & $655 \mathrm{Min} \mathrm{MPa}$ \\
\hline Elongation A50 mm & $40 \mathrm{~min} \%$ \\
\hline
\end{tabular}

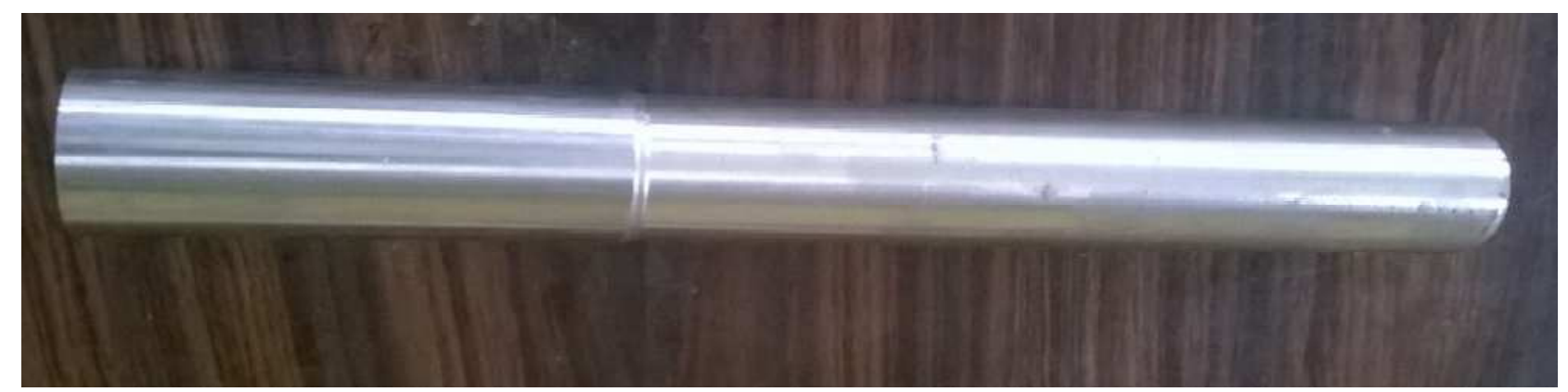

Figure 5: Stainless Steel AISI-202 rod.

\section{EXPERIMENTAL PROCEDURE}

The experimental procedure was carried out with flow chart. The experiment is performed in two working environments.Turning operations performed on two materials, MS and AISI-202 in dry machining as well as chilled air supply machining. The single point HSS cutting tool is used for both MS and AISI-202. 


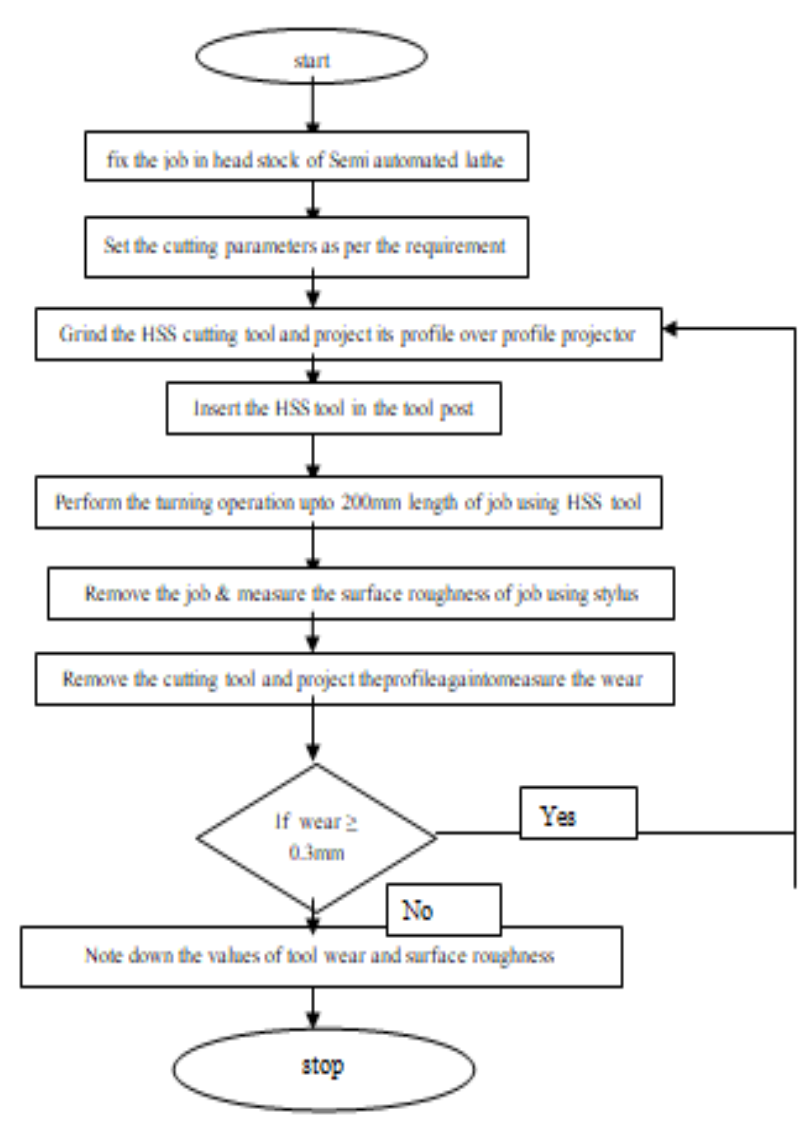

Figure 6: Flow Chart of Machining Procedure Dry Air Machining.

4.1. Experimental Values

Table 7: Turning on Tempered Mild Steel using HSS Tool

\begin{tabular}{|c|c|c|c|c|c|c|c|}
\hline $\begin{array}{c}\text { S. } \\
\text { No }\end{array}$ & $\begin{array}{l}\text { Speed } \\
\text { (v) } \\
\text { (in } \\
\text { rpm) }\end{array}$ & $\begin{array}{l}\text { Feed } \\
(\mathbf{f}) \\
(\mathrm{mm} \\
/ \mathrm{rev})\end{array}$ & $\begin{array}{l}\text { DOC } \\
\text { (d) } \\
\text { (in } \\
\text { mm) }\end{array}$ & $\begin{array}{c}\text { Surface } \\
\text { Roughness }\left(\mathbf{R}_{\mathrm{a}}\right) \text { in } \\
\text { Dry Air Machining } \\
(\text { in } \mu \mathrm{m})\end{array}$ & $\begin{array}{c}\text { Surface } \\
\text { Roughness }\left(\mathbf{R}_{\mathrm{a}}\right) \text { in } \\
\text { Cool Air Machining } \\
(\text { in } \mu \mathrm{m})\end{array}$ & $\begin{array}{l}\text { Tool Wear in } \\
\text { Dry Air } \\
\text { Machining } \\
\text { (in mm) }\end{array}$ & $\begin{array}{l}\text { Tool Wear in } \\
\text { Cool Air } \\
\text { Machining } \\
\text { (in mm) }\end{array}$ \\
\hline 1 & 180 & 0.75 & 0.4 & 0.93 & 0.76 & 0.05 & 0.04 \\
\hline 2 & 180 & 1.25 & 1.0 & 0.99 & 0.84 & 0.06 & 0.05 \\
\hline 3 & 280 & 0.75 & 0.4 & 1.18 & 0.95 & 0.07 & 0.06 \\
\hline 4 & 280 & 1.25 & 1.0 & 1.63 & 1.45 & 0.09 & 0.08 \\
\hline 5 & 450 & 0.75 & 0.4 & 1.93 & 1.61 & 0.12 & 0.10 \\
\hline 6 & 450 & 1.25 & 1.0 & 2.24 & 1.83 & 0.15 & 0.12 \\
\hline 7 & 710 & 0.75 & 1.0 & 2.50 & 1.91 & 0.14 & 0.12 \\
\hline 8 & 710 & 1.25 & 0.4 & 2.86 & 2.24 & 0.19 & 0.17 \\
\hline
\end{tabular}

Table 8: Turning Operation on Stainless Steel AISI-202 with HSS Tool

\begin{tabular}{|c|c|c|c|c|c|c|c|}
\hline $\begin{array}{c}\text { S. } \\
\text { No }\end{array}$ & $\begin{array}{l}\text { Speed } \\
\text { (v) } \\
\text { (in } \\
\text { rpm) }\end{array}$ & $\begin{array}{l}\text { Feed } \\
\text { (f) } \\
(\mathrm{mm} \\
\text { /rev) }\end{array}$ & $\begin{array}{l}\text { DOC } \\
\text { (d) } \\
\text { (in } \\
\text { mm) }\end{array}$ & $\begin{array}{c}\text { Surface } \\
\text { Roughness }\left(\mathbf{R}_{\mathrm{a}}\right) \text { in } \\
\text { Dry Air Machining } \\
(\text { in } \mu \mathrm{m})\end{array}$ & $\begin{array}{c}\text { Surface } \\
\text { Roughness }\left(\mathbf{R}_{\mathrm{a}}\right) \text { in } \\
\text { Cool Air Machining } \\
(\text { in } \mu \mathrm{m})\end{array}$ & $\begin{array}{l}\text { Tool Wear in } \\
\text { Dry Air } \\
\text { Machining } \\
\text { (in mm) }\end{array}$ & $\begin{array}{l}\text { Tool Wear in } \\
\text { Cool Air } \\
\text { Machining } \\
\text { (in mm) }\end{array}$ \\
\hline 1 & 180 & 0.75 & 0.4 & 0.76 & 0.69 & 0.16 & 0.13 \\
\hline 2 & 180 & 1.25 & 1.0 & 0.82 & 0.72 & 0.18 & 0.15 \\
\hline 3 & 280 & 0.75 & 0.4 & 0.79 & 0.69 & 0.22 & 0.18 \\
\hline 4 & 280 & 1.25 & 1.0 & 0.89 & 0.68 & 0.26 & 0.21 \\
\hline 5 & 450 & 0.75 & 0.4 & 1.12 & 0.89 & 0.27 & 0.23 \\
\hline 6 & 450 & 1.25 & 1.0 & 1.29 & 1.01 & 0.29 & 0.26 \\
\hline
\end{tabular}



Dry Machining of MS and AISI-202

\begin{tabular}{|l|l|l|l|l|l|l|l|}
\hline 7 & 710 & 0.75 & 1.0 & 1.13 & 0.92 & 0.32 & 0.29 \\
\hline 8 & 710 & 1.25 & 0.4 & 1.45 & 1.11 & 0.36 & 0.31 \\
\hline
\end{tabular}

\section{RESULTS}

The present study, describes the cool air supply of HSS single point cutting tool and it's work piece. The single point cutting tool has significant influence on it's surface roughness. Surface roughness values are improved up to $24 \%$ and $23.49 \%$ and the tool life improved up to $20 \%, 19.23 \%$ respectively. While machining Mild Steel, Stainless Steel AISI-202 the tool wear was reduced.

\section{CONCLUSIONS}

The tool life of HSS can be improved significantly, economically and eco friendly by simple installation of cool air supply at tool-work piece interface. By reducing the tool wear and improvement of surface finish, the tool life has been enhanced. These recommendation will aid small and medium machining shops. Further study over tool-work piece interface point heat generation and impact of conduction or convection heat transfer coefficients can find out which temperature is optimum for which tool and work piece by incorporating heat transfer and material science knowledge.

\section{REFERENCES}

1. Sharma, A. V. N. L., \& Satyanarayana Raju., PGopichand and Subbaiah., Optimization of cutting parameters on mild steel with HSS \& Cemented Carbide Tipped tools using ANN. International Journal of Research in Engineering and Technology, ISSN: 2319-1163.

2. Baba, M., C. Tumba, and A. Issa. "Formulation and Performance Assessment of Fixed Oils Based Cutting Fluids in Machining Operation." Int. J. Mech. Eng 7.6 (2018): 11-22.

3. Lee, J. H., \& Lee S.J. (2001) .Environment-friendly cutting process technology. Journal of the Korean Society for Precision Engineering, 18, 31-36.

4. AdestaErryYulian T., \&Riza Muhammad. (2009) .HazzaMuataz and AgusmanDelvis : Tool Wear and Surface Finish Investigation in High Speed Turning Using Cermet Insert by Applying Negative Rake Angles . European Journal of Scientific Research, Vol.38 No.2: pp.188.

5. Ali S.M., \&Dhar, N.R., (2010). Tool Wear and Surface Roughness Prediction using an artificial Neural Network in Turning Steel under Minimum Quantity Lubrication. International Conference on Industrial Engineering ICIE, WASET Conference Proceedings, 62(4), 607-616.

6. Young Kug Hwang., \& Choon Man Lee., (2010). Surface roughness and cutting force prediction in MQL and wet turning process of AISI 1045 using design of experiments. Journal of Mechanical Science and Technology, 24 (8) 1669-1677 